\author{
MILOŠ JAGODIĆ \\ University of Belgrade, Faculty of Philosophy \\ mjagodic@f.bg.ac.rs
}

\title{
SERBIAN SECRET ORGANISATION IN EASTERN BOSNIA (1849-1855) ${ }^{*}$
}

\begin{abstract}
The article shows and analyzes activities of the Serbian secret organization in eastern Bosnia from 1849 to 1855. It is demonstrated that the goals of the organization by 1851 included the preparation of an uprising against the Turkish rule, but from that point on it served as an intelligence agency with a task to gather information on the circumstances in Bosnia and Herzegovina. The most important features of the organization structure are underlined and certain activities as well as its weaknesses are pointed out. The article is based mostly upon the unpublished archival material of Serbian origin.

Keywords: Bosnia, Serbia, secret organization, Ilija Garašanin, Toma Kovačević, Pavle Marinović, Užice.
\end{abstract}

$\mathrm{I}$ n 1844 the Serbian Principality Minister of Interior, Ilija Garašanin, along with his associates made a strategic plan regarding the national and foreign policy called the Načertanije. The aim was the restoration of the Serbian Empire based on the historical law which would, as a balancing element between the European countries, replace Turkey in Europe as its fall was deemed inevitable. ${ }^{1}$ The implementation of the Načertanije meant the collaboration of Serbia with Christians in the Balkans. Therefore, in 1849 a Serbian secret organization was formed and its network of agents covered several European provinces of the Ottoman Empire. Historiography holds texts about the organization, but more as a general overview than in detail. ${ }^{2}$ The aim of this article is to show and analyze the organization activities in eastern Bosnia based on reports of an agent stationed in Užice. Dušan Berić used the same reports, but mostly as sources about the background of an

\footnotetext{
* Research for the paper was funded by the Ministry of Education, Science and Technological Development of the Republic of Serbia as a part of a project Serbian Nation: integrative and disintegrative processes (Reg. No. 177014).

${ }^{1}$ For a detailed analysis of the Načertanije and literature about it, see: Ljušić $2003^{2}$. The latest works on the Načertanije: Bataković 2015; Nikiforov 2015.

2 Stranjaković 1932: 272-274; Stranjaković 1936; Kecmanović 1962: 251-291; Berić 1994: 165-188; Ekmečić 1997: 25-32; Jagodić 2016: 115-126.
} 
uprising in Herzegovina in 1851-1853. ${ }^{3}$ All the dates in the main text are given by the Gregorian, modern day calendar, while in the notes, in quoting the documents, dual dating is applied.

Quite serious work on implementing the Načertanije started in spring of 1848 as the revolution broke out in Europe. Garašanin engaged certain secret agents to inquire about the general mood and readiness of the Christian population for an uprising in the European provinces under the Turkish rule. At the same time a Serbian diplomatic agent in Constantinople, Konstantin Nikolajević, devised a project for creating a Serbian Viceroyalty under the Ottoman Empire, which would include most of the European Turkey, thus transforming the Ottoman Empire into a dual monarchy. Deeming that favorable conditions had been created, Garašanin accepted the plan and tried to carry it out in the summer of 1848, supported by the Polish emigration in Constantinople. He thought that the Porte would concede to such terms in order to achieve durable pacification of the Christians in its European lands. But since it was not a realistic plan and was not backed by the French diplomacy, the Turks rejected it. ${ }^{4}$ Then the Serbian attention was drawn to the revolution in Hungary and to providing active assistance to the Serbs in Serbian Vojvodina.

In the March of 1849 Ilija Garašanin started planned, systematic and organized activities on preparing an uprising of the Serbs and other Christians against the Turkish rule. He and his chief associates, Jovan Marinović, Matija Ban and Toma Kovačević, drafted a Constitution of the Political Propaganda to be implemented in the Slavic-Turkish lands. At the approval of Prince Aleksandar Karađorđević, the Constitution was in effect from June of 1849 to May of 1850 and later on a revised version was implemented. It specified a conspiracy network of Serbian agents in a great part of the Balkan Peninsula. Their task was to make preparations for a simultaneous uprising of the Christians. The center of the organization was in Belgrade and Ilija Garašanin was at its head. His chief associate was Jovan Marinović. The entire area covered by the organization was split into two parts: the northern and the southern one, each with its own head of the activities. The chief of the former was Toma Kovačević, while Matija Ban was the chief of the latter. The northern part included Bosnia, an area between the southern border of Serbia and northern Albania, northern Albania (Mirdite) and south-western Bulgaria. The southern part included Dalmatia, Herzegovina, Montenegro and Albania. Those two parts were then further divided into smaller territorial units, areas and each area had its agent as a propaganda manager. Those agents received a modest compensation for their work. The northern part was divided into seven areas with centers at Jasenovac, Brod, Rača (of Šabac), Mokra Gora, Raška, Gurgusovac and Aleksinac. The area included one or more nahiye. An agent was supposed to select a chief of the organization in each nahiye. The office duty was not a paid one. The individual organization chiefs were not supposed to know about each other or about Garašanin, but only about their agent and the chief. It was a way to protect the conspiratorial nature of the organization. A liaison between an agent and the nahiye chief was to be maintained by a suitable person called 'a boy'. He received a modest pay and was subordinate to the agent. His duty was also to pay regular visits to the nahiye chiefs,

\footnotetext{
${ }^{3}$ Berić 1994: 191-230, 236-238, 241, 270-271.

${ }^{4}$ Milićević 1973: 89-110; Ekmečić 2000: 186; Ljušić 2003: 131; Bataković: 174; Jagodić 2016: 95-97, 115-118.
} 
controlling their activities. The nahiye chiefs were supposed to gather intelligence on their territory and to select a kmet, a chief of a local organization in each town or village. Also the kmets were not supposed to know about each other. Their task was to maintain faith in the pending liberation among the Christian population and to advise them to get weapons and ammunition. When the uprising was about to break out, the kmets were supposed to lead the local squads. If possible, priests were to be appointed as the nahiye chiefs and. In places where the population was mixed, Muslims and Christians, the organization was not supposed to be formed due to a risk of treason. The correspondence within the organization could be performed either in normal language or in code, in mercantile terms. The Constitution envisioned first to gather intelligence relevant to raising a revolt in each nahiye (geographical features, the number of people of different denominations eligible for war, weapons held by the population, Turkish military power, etc.) and then to make two types of plans: one of general nature and several quite particular ones for each area separately. The aim was to cause revolt in all the places simultaneously and for the insurgents to, suddenly and most efficiently, tackle the resistance of the Turkish army and the Muslim population and to occupy important locations and towns. The total budget of the propaganda was a modest amount of 3,400 talers. $^{5}$

The area of an agent residing in the Mokra Gora range included eastern Bosnia. However, from the very start of the organization, his permanent residence was in Užice and not in Mokra Gora. The reason behind this was most probably the fact that Toma Kovačević appointed Pavle Marinović, an Užice teacher, as an agent. He was originally from Dubrovnik. He had attended a Christian Orthodox Seminary in Šibenik. Due to his young age he was not allowed to become a priest so, being without any income, he came to Serbia in 1842. It is not known what he had been doing by 1845 but in that year he became a teacher in Ivanjica and in the following year he moved to Užice. In December of 1852 he became a clerk at the Užice County Regional Administration. ${ }^{6}$

At the beginning of August 1849 Marinović found a suitable person to be 'a boy', but his identity remains unknown. He did his first round of the area in August of 1849. He visited Višegrad, Rogatica and Srebrenica. A fact is worth mentioning that says a lot about how few basic things they knew about the circumstances in this part of Bosnia - Marinovic was surprised to hear that in that area there were no nahiye as administrative units, only kazas. The boy was not able to appoint priests as organizations chiefs. In the Višegrad kaza there was only one and he could not find that one at home. In the kaza of Srebrenica there were a few priests but none of those he talked to were willing to participate in the organizational activities or preparations for the uprising against the Turkish rule. So, the boy contacted some reliable peasants, won them over for the organization and appointed them as "nahiye” chiefs. In the kaza of Višegrad those were Vuk Nešković and Sava Jovičić from the village of Bijelo Brdo near the Serbian border, opposite Mokra Gora. In the kaza

\footnotetext{
${ }^{5}$ Stranjaković 1936: 12-22; Jagodić 2016: 118-120; Arhiv Srbije (Archives of Serbia) (=AS), Ilija Garašanin (=IG), 647.

${ }^{6}$ Popović 1999: 229; AS, Zbirka Dragoslava Stranjakovića (Dragoslav Stranjaković’s Collection) (=ZDS), Fascika (File) (=F) 1, spisak (list) (=sp.) 5, Dokumenta za istoriju Bosne i Hercegovine (Documents on history of Bosnia and Herzegovina) 1848-1854, P. Marinović to T. Kovačević, № 16, 25. 6/7. 7. 1852; [№ 26] 5/17. 12. 1852; № 27, 17/29. 12. 1852, Užice.
} 
of Srebrenica five peasants agreed to participate in the organization activities: Filip Ravanac from the village of Ravni Brijeg, brothers Petar and Ilija Borovčan from the village of Borovac, Nikola from the village "Podplaninom"7 and Mihailo Soldat from the village of

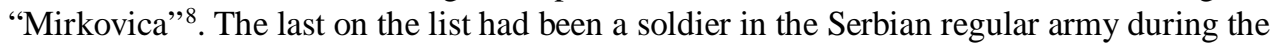
reign of Prince Miloš Obrenović. They all readily agreed to work on the preparations for the uprising, promising to further extend the organization. Since the kaza of Rogatica consisted of extremely mixed Muslim and Christian population, the boy never revealed the true aim of his travels to anyone there. The first intelligence came from the engaged peasants about the number of houses and the male population of either Christian or Muslim faith, their material condition and professions, about the land configuration, strategic structures and the state of the Turkish army in the said kazas. ${ }^{9}$

Since some dilemmas about the Užice area organization territorial perimeter had been resolved, Marinović gave the boy a task for his next round in the area in November 1849 to find some suitable men and to appoint them as chiefs in the kazas of Vlasenica and Glasinac. In the former he appointed priest Marko from the village of Lipovac and in the latter priest Ilija of Glasinac. By that time, in the kaza of Srebrenica, Mihailo Soldat had already selected and appointed the kmets, but Filip Ravanac then had a change of heart and refused any collaboration. So, once again, the boy failed to form an organization in the kaza of Rogatica. He just passed through the kaza of Višegrad as he could not find Sava Jovičić at home. Later on, in December, he sent him a description of that kaza. ${ }^{10}$

In February 1850, after his round of the area, the Marinović's boy submitted a report with a description of the entire area. However, there is a confusion regarding the statement that Glasinac belonged to the kaza of Rogatica. He included the kaza of Nova Varoš in the area on his own. Based on a later report of Pavle Marinović, it could be concluded that the duty of the chief of the Nova Varoš kaza was performed by the Višegrad chief, Sava Jovičić. In the context of the preparations for the uprising, the most important information provided in this and other earlier reports was that about half of the Serbs eligible for war in those kazas were well equipped with weapons. Marinović's boy made another round of the area in March 1850 and after that submitted a short and rather insubstantial description of the kaza of Rogatica. ${ }^{11}$ In that same month at Kovačević's request Marinović sent him a list of sixteen Serbs, emigrants from Turkey, who lived in Užice and who were ready to participate in the uprising in Turkey. ${ }^{12}$ That same month Kovačević received an analogous list from the

\footnotetext{
${ }^{7}$ It is possible that Marinovic misread the name of the village, for we were unable to locate the village called Podplaninom on the map. It was supposedly located in the Osat region. There is, however, a village called Podravno in that region.

${ }^{8}$ Again, we could not find a village of that name in the Osat region. There is a village called Markovići in that region.

${ }_{9}^{9}$ AS, ZDS, F 1, sp. 5, Dokumenta za istoriju Bosne i Hercegovine 1848-1854, P. Marinović to T. Kovačević, № 2, 12/24. 8. 1849, Užice; Berić 1994: 176.

${ }^{10}$ AS, ZDS, F 1, sp. 5, Dokumenta za istoriju Bosne i Hercegovine 1848-1854, P. Marinović to T. Kovačević, № 3, 21. 9/3. 10. 1849; № 4, 22. 10/3. 11. 1849; № 5, 5/17. 11. 1849; № 6, 10/22. 12. 1849, Užice.

${ }^{11}$ Ibid., P.Marinović to T. Kovačević, № 7, 4/16. 1. 1850; № 8, 18/30. 1. 1850; № 9, 10/22. 2. 1850; № 10, 16/28. 2. 1850; № 12, 10/22. 3. 1850, Užice.

${ }^{12}$ Ibid., P. Marinović to T. Kovačević, № 11, 9/21. 3. 1850, Užice; Berić 1994: 175.
} 
agent in Aleksinac, Sava Radojičić, whose area included the sanjak of Niš ${ }^{13}$ so it could be concluded that Toma Kovačević was seriously thinking of starting a revolt in the spring of 1850.

However, it never happened. In the spring of 1850 Matija Ban and Toma Kovačević started summing up the hitherto achieved results. They both agreed that there was no need for the boys anymore as their frequent travels were drawing attention to themselves, thus breaching the secrecy of the organization, as well as posing an unnecessary expenditure. Kovačević suggested that Matija Ban be replaced by a Dubrovnik priest, Đorđe Nikolajević and a necessary military plan should be made certainly by May $1851 .^{14}$

It seems that from May 1850 Marinović started a direct correspondence with the "nahiye" chiefs who sent him letters via the officials of the Mokra Gora border crossing. His boy made his last round of the Užice area in July 1850 and he was dismissed as the decision was made to discharge them. On that occasion he submitted a report on the number of male inhabitants, both Serbs and Turks, in the four kazas, which was included in the annual report that Toma Kovačević sent to Garašanin. The data are given in Table 1. Discharging the boys as intermediaries between the nahiye chiefs and agents ended a phase in the organization activity. The fact that conspiracy in eastern Bosnia was not maintained on a high level is evident in that the chiefs of Rogatica and Višegrad knew about each other and moreover had a great relationship. ${ }^{15}$

\begin{tabular}{||l|c|c|c|c||}
\hline \multirow{2}{*}{ Kaza } & \multicolumn{4}{|c|}{ Men, 12-80 years old } \\
\cline { 2 - 5 } & \multicolumn{2}{|c|}{ Turks } & \multicolumn{2}{c|}{ Serbs } \\
\cline { 2 - 5 } & total & armed & total & armed \\
\hline Srebrenica & 2300 & 1200 & 3000 & 1000 \\
\hline Rogatica & 3000 & 2000 & 1100 & 700 \\
\hline Višegrad & 978 & 536 & 766 & 132 \\
\hline Nova Varoš & 1480 & 800 & 963 & 435 \\
\hline
\end{tabular}

Table 1 - Male inhabitants in four kazas of Eastern Bosnia

In the second half of 1850, by Kovačević's order, Marinović undertook two significant actions. Immediately upon the arrival of Omer-Pasha Latas in Bosnia in early July, in order to quash the resistance of the Bosnian beys towards the Tanzimat reforms, Marinović ordered the chiefs to organize Serbian deputations from all the regions that presented their complaints to Omer-Pasha about the conditions and repression they suffered from the Turks. In October he arranged a transfer of school textbooks from Serbia to Srebrenica to a primary school there. ${ }^{16}$

${ }^{13}$ AS, ZDS, F 3, sp. 12, XXII 1850 , S. Radojčić to T. Kovačević, 28. 2/12. 3. 1850, Aleksinac.

${ }^{14}$ Stranjaković 1936: 24-26; Jagodić 2016: 123; AS, IG, 644, 647.

${ }^{15}$ AS, ZDS, F 1, sp. 5, Dokumenta za istoriju Bosne i Hercegovine 1848-1854, P. Marinović to T. Kovačević, № 13, 13/25. 5. 1850; № 14, 17/29. 6. 1850; № 16, 8/20. 7. 1850, Užice; IG, 651.

${ }^{16}$ AS, ZDS, F 1, sp. 5, Dokumenta za istoriju Bosne i Hercegovine 1848-1854, P. Marinović to T. Kovačević, № 
In October 1850 the Višegrad and Nova Varoš kaza chief was contacted by a certain priest from Sarajevo, Sophronius, who, using a mercantile code, informed him that the wheat gave a good yield but that there were no buyers, so that it would be good if someone from the neighborhood could come and buy it. It meant that he asked for someone to come from Serbia to organize an uprising, deeming that the disposition of the people was favorable. ${ }^{17}$

In December 1850 the Serbs from Srebrenica, Vlasenica and other surrounding kazas found themselves in a rather awkward position. The insurgent Bosnian Muslims invited and pressured them to join them in the struggle against Omer-Pasha Latas' army. The Srebrenica chief, Mihailo Soldat, managed to avert his compatriots from joining the war on his own initiative. He deemed that it would be bad for Serbs if the Bosnian insurgents won. Furthermore, in late December he intended to incite Serbs to a revolt against the Turkish rule, considering it was a right moment as the Turks were busy with their internal armed conflicts. However, by Marinović's order, a Srebrenica teacher, Janićije Milovanović, averted him from his plan. By the way, he was the one who wrote Soldat's letters to the agent in Užice as the chief was illiterate. ${ }^{18}$ Soldat's actions were the result of his impatience and perhaps even a discontent because Serbia hesitated to start the struggle for the liberation from the Turkish rule.

From the second half of 1850 Marinović increasingly started dedicating his reports to the general circumstances in Bosnia, which he gathered from various travelers and from more or less reliable people who were coming from Turkey, rather than to the work of the organization. In October he contacted priest Nikola Popović from the village of Babine near Prijepolje, who brought his younger brothers to Užice for schooling. From that time until his death in 1853, Nikola remained Marinović's regular and reliable informant about events in Herzegovina. ${ }^{19}$

The above mentioned trend of reporting continued all through 1851 and 1852. Marinović seldom wrote about the organization in his area, usually just a short sentence, nothing new. On the other hand, the reports he regularly sent contained various intelligence about the general situation in Bosnia and Herzegovina, about the movements of the Turkish army, the conflicts with the Muslim insurgents and about the revolts of the Serbs in Herzegovina in 1851 and 1852. Moreover, in two years he wrote about one chief only three times and it was the Srebrenica chief, Mihailo Soldat. And the last time it was just en passant, reporting in August 1852 that the teacher from the same place died. In August 1852 priest Dimitrije Popović became a regular informant from the kazas of Nova Varoš and Višegrad, which meant that the contact with the chief of the organization was broken. Therefore, it could be argued with certainty that as of 1851 the secret organization in eastern Bosnia lost its original function aimed at preparations for an uprising of the Serbs. From

18, 28. 7/9. 8. 1850; № 22, 20. 9/2. 10. 1850; № 25, 4/16. 11. 1850, Užice; Šljivo 1977: 66-67.

${ }^{17}$ AS, ZDS, F 1, sp. 5, Dokumenta za istoriju Bosne i Hercegovine 1848-1854, P. Marinović to T. Kovačević, № 25, 4/16. 11. 1850, Užice.

${ }^{18}$ Ibid., P. Marinović to T. Kovačević, № 28, 2/14. 12. 1850; № 29, 6/18. 12. 1850; № 30, 19/31. 12. 1850; № 13, 21. 5/2. 6. 1852, Užice.

${ }^{19}$ Ibid., P. Marinović to T. Kovačević, without №, 21. 10/2. 11. 1850; № 26, 10/22. 11. 1850; № 30, 19/31. 12. 1850; № 6, 7/19. 3. 1853, Užice; Bosanska vila 7 (1905), 103-104. 
that point on Marinović acted from Užice, not as an organizer of the uprising in eastern Bosnia but as an intelligence agent. Since in early 1852 the Turkish authorities confiscated the weapons from the Serbs in Bosnia as a preventive measure, the most important prerequisite for a successful uprising was thus extinguished. ${ }^{20}$

We have found only ten of Marinović's letters to Kovačević from 1853 and the last one was from June of the same year. They show that Marinović knew that Ilija Garašanin was the head of the organization. There is also an important fact that Marinović's intelligence activity did not cease after Garašanin left the ministerial office in the Serbian government. From the content of the letters we can conclude that Marinović received instructions from Kovačević to maintain contacts with the people in Turkey and to send him reports as before. ${ }^{21}$

We had only two of Marinović's letters from 1854 and from 1855 respectively and they, in their own right, are evidence that he continued with his intelligence activity. The last of the letters shows that there was an attempt to replace priest Nikola as an informant with another priest Josif, who was probably a brother of the late Nikola Popović. The attempt failed as Josif was not able to find any reliable sources of information. Obviously, because of the Crimean War that was in progress, people were reluctant to get engaged in that sort of activity. ${ }^{22}$ How long Marinović exactly worked as an intelligence agent for Kovačević remains unknown. Just to make a comparison, it is known that the secret organization's former chief in the kaza of Priština, merchant Vasilije Đorđević, also used to send reports to Kovačević in $1854 .{ }^{23}$ So it is clear that the intelligence work that originated in the organization established in 1849 did not cease when Garašanin left his office, but continued in the years to follow. For now we cannot say whether it lasted continuously until he returned to the office in 1858 or not.

There are also some facts in the life of Pavle Marinović which are significant to a certain extent for the secret organization background and which Marinović revealed in his letters to Kovačević, but which were not related directly to his conspiratorial activities. Marinović was rather discontent with his financial position. In several of his letters he complained to Kovačević that his teacher's salary was rather small and even with a modest compensation of 76 talers a year that he received for his work as an agent, he was not able to support his family. So he constantly asked Kovačević to use his influence and to find him

${ }^{20}$ Ibid., P. Marinović to T. Kovačević, № 33, 17/29. 1. 1851; № 34 27. 1/8. 2. 1850; № 36, 14/26. 2. 1851; № 37 , 17/29. 3. 1851; № 39, 18/30. 4. 1851; № 40, 2/14. 5. 1851; № 41, 23. 5/4. 6. 1851; № 42, 2/14. 6. 1851; № 43, 11/23. 7. 1851; № 44, 25. 7/6. 8. 1851; № 45, 11/23. 8. 1851; № 1, 12/24. 9. 1851; № 2, 29. 9/11. 10. 1851; № 5, 5/17. 12. 1851; № 1, 9/21. 1. 1852; № 7, 26. 1/7. 2. 1852; № 9, 20. 2/3. 3. 1852; № 10, 12/25. 3. 1852; № 11, 12/24. 4. 1852; № 12, 26. 4/8. 5. 1852; № 13, 21. 5/2. 6. 1852; № 14, 24. 5/5. 6. 1852; № 16, 25. 6/7. 7. 1852; № 17, 18/30. 7. 1852; № 18, 9/21. 8. 1852; № 19, 27. 8/8. 9. 1852; № 20, 2/14. 10. 1852; № 21, 10/22. 10. 1852; № 23, 22. 10/3. 11. 1852; № 23, 29. 10/10. 11. 1852; № 24, 9/21. 11. 1852; № 25, 26. 11/8. 12. 1852; without №, 5/17. 12. 1852; № 27, 17/29. 12. 1852; № 28, 24. 12. 1852/5. 1. 1853 .

${ }^{21}$ Ibid., P. Marinović to T. Kovačević, № 2, 14/26. 1. 1853; № 4, 31. 1/12. 2. 1853; № 5, 25. 2/9. 3. 1853; № 6, 7/19. 3. 1853; № 8, 8/20. 3. 1853; № 7, 14/26. 3. 1853; without №, 29. 3/10. 4. 1853; № 9, 22. 4/4. 5. 1853; № 10, 23. 5/4. 6. 1853, Užice.

${ }^{22}$ Ibid., P. Marinović to T. Kovačević, № 8, 8/20. 9. 1854; № 13, 8/20. 12. 1854; № 15, 9/21. 2. 1855; without №, 14/26. 5. 1855, Užice; Bosanska vila 7 (1905), 104.

${ }^{23}$ Jagodić 2015: 195-206. 
some office work at the Užice County Administration. He even tried to ingratiate himself with Kovačević by sending him the famous Užice cheese and curded cream to Belgrade. Those complaints ceased only when he became a clerk at the Užice County in December 1852. On the other hand, in July 1852, with the help of priest Đorđe Nikolajević, Marinović sold his house in Dubrovnik with an idea to use the money and buy one in Belgrade. He obviously planned to move to the capital eventually and continue his life and career there. ${ }^{24}$ Hence a logical question: did he view his work in the secret organization as a sure investment for his future life? And once again as a comparison, we state here that the agent from the Aleksinac area, Sava Radojčić was also quite dissatisfied with his financial status and a job of a municipal court clerk, so he also asked Kovačević to find him a better paid job. Therefore, undoubtedly, a small budget of the organization, initially founded in 1849, was actually a disadvantage. ${ }^{25}$

Based on all the facts presented so far, we can conclude the following. The Serbian secret organization aimed at preparing an uprising against the Turkish rule became active in eastern Bosnia in 1849 and functioned as initially intended until 1851. However, the organization rules that had been defined in the Propaganda Constitution were not observed in full. Since Serbia did not make a decisive step to start a liberation war and did not even make a war plan for the insurgents, in 1851 the organization was transformed into some sort of an intelligence agency. Ilija Garašanin's withdrawal from the office in 1853 did not cause the intelligence work to cease. We can argue with certainty that the agent in charge of eastern Bosnia, Pavle Marinović, continued to supply the information about the circumstances in Bosnia until June 1855. But we cannot make any judgment about the organization's real strength with regard to the uprising as it was never tested in practice.

\section{REFERENCES:}

Unpublished sources and abbreviations:

Arhiv Srbije [Archive of Serbia] - AS

Ilija Garašanin - IG

Zbirka Dragoslava Stranjakovića [Dragoslav Stranjaković’s Collection] - ZDS

References:

Bataković, D. The Foreign Policy of Serbia (1844-1867): Ilija Garašanin’s Načertanije, Belgrade: Institute for Balkan Studies, Serbian Academy of Sciences and Arts, 2015.

Berić, D. Ustanak u Hercegovini 1852-1862, Beograd, Novi Sad: Srpska akademija nauka i umetnosti, 1994. (Serbian Cyrillic)

Ekmečić, M. „Garašan, Čartoriski i Mađari 1848-1849. godine“, u Ekmečić, M. Revolucija 1848. i Balkan, Novi Sad: Matica srpska, 2000, 163-212. (Serbian Cyrillic)

${ }^{24}$ AS, ZDS, F 1, sp. 5, Dokumenta za istoriju Bosne i Hercegovine 1848-1854, P. Marinović to T. Kovačević, № 6, 10/22. 12. 1849; № 22, 20. 9/2. 10. 1850; without №, 21. 10/2. 11. 1850; № 28, 2/14. 12. 1850; № 30, $19 / 31$. 12. 1850 ; № 42, 2/14. 6. 1851; № 1, 12/24. 9. 1851; № 5, 5/17. 12. 1851; № 13, 21. 5/2. 6. 1852; № 16, 25. 6/7. 7. 1852; № 17, 18/30. 7. 1852; № 18, 9/21. 8. 1852; № 20, 2/14. 10. 1852; № 27, 17/29. 12. 1852.

${ }^{25}$ Jagodić 2016: 121-122. 
. „Nacionalna politika Srbije prema Bosni i Hercegovini i agrarno pitanje (1844-1875)“, u Ekmečić, M. Radovi iz istorije Bosne i Hercegovine XIX veka, Beograd: BIGZ, 1997, 25-45. (Serbian Cyrillic)

Jagodić, M. „Izveštaj Vasilija Đorđevića o događajima u Staroj Srbiji iz jula 1854“, Mešovita građa. Miscellanea, 36, 2015, 195-206. (Serbian Cyrillic)

. Srbija i Stara Srbija (1839-1868). Nasleđe na jugu, Beograd: Evoluta, 2016. (Serbian Cyrillic)

Kecmanović, I. „Izveštaji poverenika o prilikama u Bosni od 1848. do 1854. godine“, Glasnik arhiva i Društva arhivista Bosne i Hercegovine, 2, 1962, 251-291.

Ljušić, R. Knjiga o Nečertaniju, Kragujevac: Jefimija, 2003². (Serbian Cyrillic)

Milićević, J. „O Bosni 1848. godine“, Istorijski glasnik, 1, 1973, 89-110. (Serbian Cyrillic)

Nikiforov, K. V. „Načertanie“ Ilii Garašanina i vnešnjaja politika Serbii: v 1842-1853 gg., Moskva: Indrik, 2015. (Russian Cyrillic)

Popović, Lj. Šematizam Kneževine Srbije 1839-1851, Beograd: Arhiv Srbije, 1999. (Serbian Cyrillic) „Prota Babinski Jefta Popović“", Bosanska vila, 7, 1905, 103-106. (Serbian Cyrillic)

Stranjaković, D. Politička propaganda Srbije u jugoslovenskim pokrajinama 1844-1858. godine, Beograd: 1936. (Serbian Cyrillic)

. Vlada ustavobranitelja 1842-1853. Unutrašnja i spoljašnja politika, Beograd: 1932. (Serbian Cyrillic)

Šljivo, G. Omer-paša Latas u Bosni i Hercegovini 1850-1852, Sarajevo: Svjetlost, 1977.

\section{МИЛОШ ЈАГОДИТ}

Универзитет у Београду, Филозофски факултет

\section{СРПСКА ТАЈНА ОРГАНИЗАЦИЈА У ИСТОЧНОЈ БОСНИ (1849-1855)}

\section{Резиме}

На темељу Начертанија, министар унутрашњих дела Кнежевине Србије, Илија Гарашанин, започео је плански организован рад на припреми устанка Срба и других хришћанских народа на Балкану у пролеће 1849 . У том циљу је створена тајна организација, која је својим деловањем обухватила више европских провинција Турске. Надлежан за рад организације у Босни био је Гарашанинов сарадник Тома Ковачевић. Њему је директно био потчињен агент за источну Босну, Павле Мариновић, који је резидирао у Ужицу. Мариновић је током друге половине 1849. и 1850. формирао мрежу организације у казама Сребреница, Вишеград, Рогатица и Нова Варош. Преко начелника постављених на чело сваке од наведених каза, прикупио је важне податке о броју мушких становника православне и муслиманске вероисповести, рељефу, стратешким објектима и турским војним снагама. Утврђено је да је око половине Срба у тој области поседовало оружје и да су били спремни за устанак. Међутим, како се Србија није одлучила да отпочне ослободилачку борбу против Турака, организација се од 1851. претворила у обавештајну агентуру. Мариновић је полако губио контакт са начелницима у појединим казама, али је све више сакупљао различите податке о приликама у Босни и у Херцеговини од путника и од ругих поузданих лица. Извесно време је имао сталне дописнике из околине Пријепоља и Нове Вароши. Обавештајни рад је настављен и након одласка Илије Гарашанина са власти 1853. Поуздано се може закључити да је трајао до средине 
1855. Утврђено је да је битни недостатак организације представљао њен скроман буџет. Резултат рада тајне организације у источној Босни са аспекта припреме устанка се не може оценити, зато што устанак није био подигнут.

Кључне речи: Босна, Србија, тајна организација, Илија Гарашанин, Тома Ковачевић, Павле Мариновић, Ужице.

(C) Faculty of Philosophy, Novi Sad, 2016

ISTRAŽIVANJA - JOURNAL OF HISTORICAL RESEARCHES 27, 190-199 